\begin{tabular}{r|ll} 
AL-ISHLAH & Volume & $: 18$ \\
Nomor & $: 1$ \\
Jurnal Pendidikan Islam & Tahun & $: 2020$ \\
\hline
\end{tabular}

\title{
Efektivitas Metode Circuit Learning dalam Meningkatkan Keaktifan Belajar Siswa dalam Mata Pelajaran Qur'an Hadist
}

\author{
Partono \\ Prodi Pendidikan Agama Islam, Fakultas Tarbiyah IAIN Kudus \\ email: partono@iainkudus.ac.id
}

\begin{abstract}
This study aims to determine how the efforts of a teacher in increasing the activity of student learning in the Qur'anic lessons of Hadith through the circuit learning method. In this paper also provides a way to use the circuit learning method in learning the Qur'an hadith. By using this method it is hoped that it can influence the activeness of students in the learning process and ends in an increased understanding of the Qur'anic lessons of Hadith. Circuit learning model is one of the strategies used in the implementation of the learning process through a group approach by requiring students to develop words in their own language related to material that has been studied as a group. This research took place at MA Sultan Agung Bloar. The results of this study note that the circuit learning method is effective in increasing student learning activeness seen from students' participation in answering and giving comments in learning using their own language.
\end{abstract}

Keywords :, circuit learning; Student activity.

\begin{abstract}
Abstrak
Penelitian ini bertujuan untuk mengetahui bagaimana upaya seorang guru dalam meningkatan keaktifan belajar siswa dalam pelajaran Qur'an hadis
\end{abstract}


melalui metode circuit learning. Dalam penulisan ini juga memberikan cara bagaimana menggunakan metode circuit learning dalam pembelajaran Qur'an hadis. Dengan memakai metode ini diharapkan dapat berpengaruh terhadapkeaktifan siswa dalam proses pembelajran dan berakhir pada pemahamn yang meningkat pada pelajaran qur'an hadis. Model pembelajaran circuit learning merupakan salah satu strategi yang dipakai pada pelaksaaan proses pembelajaranmelalui pendekatan kelompok denga menuntut siswa mengembangkan kata-kata dengan bahasa mereka sendiri berkaitan dengan materi yang telah dipelajari secara kelompok. Penelitian ini mengambil lokasi di MA Sultan Agung Bloar. Hasil penelitian ini diketahui bahwa metode circuit learning efektif dalam meningkatkan keaktifan belajar siswa terlihat dari pertisipasi siswa dalam menjawab dan memberikan komentar-komentar dalam pembelajarn dengan menggunakan bahasa siswa sendiri.

Kata Kunci:, circuit learning; Keaktifan Siswa.

\section{PENDAHULUAN}

Pendidikan adalah suatu hal terpenting dalam kehidupan manusia, hal pertama yang diberikan kepada anak adalah memberi dia pengetahuan atau pendidikan, dengan adanya pendidikan membuat anak dari yang awalnya tidak mengetahui menjadi tau, yang tidak mengerti menjadi mengerti dan untuk bekal kehidupan sehari-hari dan di masa yang akan datang. Pendidikan pada dasarnya merupakan interaksi antara pendidik dan peserta didik, untuk mencapai tujuan pendidikan yang berlangsung dalam lingkungan tertentu. Interaksi ini dikenal dengan interaksi pendidikan yaitu saling pengaruh antara pendidik dengan peserta didik. Dalam interaksi tersebut peranan pendidik lebih berpengalaman, lebih banyak menguasai nilai-nilai, pengetahuan dan ketrampilan (Dalimunthe 2016). (Nana Syaodih Sukmadinata 2005, 3). Proses pembelajaran tersusun atas sejumlah 
komponen atau unsur yang saling berkaitan dan berinteraksi satu sama lain. Interaksi antara guru dan peserta didik saat proses pembelajaran berperan penting untuk mencapai tujuan yang diinginkan. Kemungkinan kegagalan guru dalam menyampaikan suatu materi pembelajaran disebabkan saat proses pembelajaran guru kurang membangkitkan perhatian dan akivitas peserta didik dalam mengikuti pelajaran(Miftahul 2013).

Qur'an hadis adalah suatu mata pelajaan yang diajarkan baik di sekolah tingkat Madrasah Ibtidaiyah (MI), Madrasah Tsanawiyah (MTS), maupun Madrasah Aliyah (MA), karena mata pelajaran ini menekankan pada kemampuan baca tulis al qur'an dengan fasih dan benar serta memahami makna secara tekstual dan kontekstual, begitu juga pada pengalaman kandungan al Qur'an dalam kehidupan sehari-hari melalui keteladanan dan pembiasaan. Pada saat ini masih ada guru yang pengajarannya menggunakan metode ceramah yang merupakan pembelajaran konvensional dan siswa masih banyak mendengarkan. Keadaan itu masih menciptakan interaksi belajar yang sifatnya satu arah sehingga kurang bermakna pada siswa. Hal ini terjadi karena proses pembelajaran yang diterapkan cenderung bersifat monoton tanpa adanya inovasi dalam penggunaan metode pada mata pelajaran qur'an hadis. Akibatnya, siswa merasa cepat jenuh dan bosan dalam menerima pelajaran yang disampaikan oleh guru. Proses pembelajaran khususnya mata pelajaran qur'an hadis, guru harus memiliki strategi agar siswa dapat belajar dengan efektif dan tidak cepat bosan dan mencapai tujuan yang diharapkan. Salah satu langkah untuk memiliki strategi itu harus menguasai model atau metode pembelajaran. Metode adalah cara atau seperangkat cara, jalan dan teknik yang digunakan oleh pendidik dalam proses pembelajaran agar peserta didik dapat mencapai tujuan pembelajaran atau kompetensi tertentu yang dirumuskan dalam silabus mata pelajaran (Hamalik 1995). Metode adalah cara yang dapat dilakukan untuk melakukan strategi. Dengan kata lain, strategi adalah a plan of operation achieving something, sedangkan metode adalah a way in achievingsomething (Rusman 2017). Metode dalam rangkain sistem pembelajaran memegang peranan penting, keberhasilan implementasi 
strategi pembelajaran sangat tergantung pada cara guru menggunakaan metode pembelajaran, karena suatu strategi pembelajaran hanya mungkin dapat diimplementasikan melalaui penggunaan metode pembelajaran (Afandi 2013).

Model pembelajaran circuit learning adalah memaksimalkan dan mengupayakan pemberdayaan pikiran dan perasaan dengan pola bertambah dan mengulang (Shoimin 2014). Circuit learning merupakan strategi pembelajaran yang memaksimalkan pemberdayaan pikiran dan perasaan dengan pola penambahan (adding) dan pengulangan (repetiton). Strategi ini biasanya dimulai dari tanya jawab tentang topik yang dipelajari, penyajian peta konsep, penjelasan tentang peta konsep, pembagian dari beberapa kelompok, pengisian lembar kerja siswa disertai dengan peta konsep, penjelasan tentang tata cara pengisisan, pelaksaan presentasi kelompok, dan pemebrian reward atau pujian. (Miftahul 2013). Model pembelajaran ini dipilih dan diterapkan untuk mata pelajaran al Qur'an hadis karena memicu peningkatan semangat belajar siswa dikarenakan akan terjadi proses tanya jawab, dan siswa dituntut untuk berfikir dan bekerja sama dengan kelompok sehingga memicu seluruh siswa berpartisipasi aktif. Pendidik memilih menggunakan model pmebelajaran ini karena juga dapat melatih kekompakan siswa dalam menyelesaikan suatu masalah, disamping itu Qur'an hadis merupakan sumber utama bagi seluruh umat Islam. Selama ini mata pelajaran Qur'an hadis yang dipelajari siswa cenderung menggunakan metode tradisional yang mungkin sebagian siswa belum tahu membaca dan sekedar mengikuti guru dan temannya membaca nyaring, sehingga pada saat ditunjuk untuk membaca sendiri masih ada masalah dalam tajwid, makna dan lain sebagainya. Kendala-kendala tersebut perlu diatasi dan dirubah dengan menggunakan metode-metode yang lebih variatif, inovatif, kreatif dan menyenangkan. Dari permasalahan diatas, diperlukan upaya agar dapat meningkatkan pemahaman siswa yang akan berpengaruh juga tehadap hasil belajar siswa. Oleh karena itu, penulis mengangkat permasalahan mengenai peningkatan pemahaman siswa dan keaktifan siswa belajar melalui model pembelajaran circuit learning pada mata pelajaran al Qur'an hadis. 
Penelitian ini termasuk dalam jenis penelitian lapangan (field research), yaitu sebuah studi penelitian yang mengambil data autentik secara obyektif/studi lapangan. Peneliti melakukan studi langsung ke lapangan untuk memperoleh data yang konkret tentang efektivitas metode circuit learning dalam meningkatkan keaktifan siswa belajar al qur'an hadist di MA Sultan Agung Blora. Penelitian ini termasuk penelitian diskriptif kualitatif. Penelitian deskriptif kualitatif adalah penelitian yang dilakukan untuk mengetahui nilai variabel mandiri, baik satu variabel atau lebih tanpa membuat perbandingan, atau menghubungan dengan variabel yang lain (Timotius 2017). Adapun data yang diperoleh pada penelitian ini bersumber pada sumber data primer, yaitu data pokok penelitian yang diperoleh langsung dari sumber data penelitian yaitu responden dengan cara wawancara, observasi dan dokumentasi. Sementara untuk sumber data sekunder, yaitu sumber data-data pendukung/pelengkap penelitian ini diperoleh dari buku/jurnal/arikel/ tulisan dari berbagai data yang mendukung dan berkaitan dengan penelitian (Anggito and Setiawan 2018)

\section{PEMBAHASAN}

Pengertian al Qur'an yaitu kalam Allah yang turunkan kepada Nabi Muhammad melalui perantara malaikat Jibril untuk disampaikan kepada umatnya. Sedangkan hadis adalah segala ucapan, perkataaan dan perbuatan yang dilakukan oleh Nabi Muhammad SAW. Secara umum Qur'an hadis menjadi sumber utama ajaran Islam, dari keduanya dijadikan pedoman hidup serta ajaran bagi manusia agar hidupnya bahagia di dunia maupun di akhirat. Namun secara khusus pengertian Qur'an hadis berasal dari kata "Qur'an " dan "hadis", dalam proses pembelajaran kemampuan membaca al Qur'an memiliki peranan penting. Karena kemampuan membaca merupakan salah satu tujuan yang ingin dicapai dalam proses pembelajaran al Qur'an hadis, dan takalah penting sikap dapat memahami pelajaran Qur'an hadis juga penting karena hal itu merupakan tujuan pembelajaran, bukan semata-mata hanya hasil belajar siswa yang tercermin dalam nilainilai dan angka-angka dalam laporan hasil akhir belajar siswa. 
Hasil belajar sering kali digunakan sebagai ukuran untuk mengetahui seberapa jauh seseorang menguasai bahan yang sudah dikerjakan. Hasil belajar dapat dijelaskan dengan memahami dua yang membentuknya, yaitu "hasil" dan "belajar" (Liatusyiam 2016). Pengertian hasil belajar adalah bila seseorang telah belajar akan terjadi perubahan tingkah laku pada orang tersebut, misalnya dari tidak tahu menjadi tahu, dan dari tidak mengerti menjadi mengerti (Hamalik 1995). Perubahan perilaku tersebut dapat diperoleh setelah siswa menyelesaikan program pembelajarannya melalui interaksi dengan berbagai sumber belajar dan lingkungan belajar. Menurut Djamarah (2000: 45), hasil adalah prestasi dari suatu kegiatan yang telah dikerjakan, diciptakan, baik secara individu maupin kelompok. Untuk menghasilkan sebuah prestasi dibutuhkan perjuangan dan pengorbanan yang sangat besar. Hanya dengan leuletan, sungguh-sungguh, kemauan yang tinggi dan rasa optimisme diriya mampu untuk mencapainya (Dewi, Wiyasa, and Ganing 2014).

Ada beberapa faktor yang mempengaruhi belajar siswa, diantaranya: 1). Metode mengajar adalah suatu cara atau jalan yang harus dilalui di dalam mengajar. Mengajar itu sendiri adalah menyajikan bahan pelajaran kepada orang lain llau diterima, dikuasai dan dikembangkan (Afandi 2013). 2). Kurikulum diartikan sebagai sejumlah kegiatan yang diberikan kepada siswa. Kegiatan ini sebagian besar adalah menyajikan bahan pelajaran agar siswa menerima, menguasai dan mengembangkan bahan pelajaran tersebut (Muhaimin 2009). 3). Relasi guru dengan siswa, Proses belajar mengajar terjadi anata guru dengan siswa. Proses tersebut juga dipengaruhi oleh relasi yang ada dialam proses itu tersendiri 4). Relasi siswa dengan siswa, siswa yang mempunyai sifat-sifat atau tingkah laku yang kurang menyenangkan bagi teman lainnya, seperti mempunyai rasa rendah diri atau sedang mengalami tekanan-tekanan batin akan diasingkan dari kelompok. Akibatnya dapat menggangu proses belajarnya dan akan berpengaruh pada hasil belajar. 4). Disiplin sekolah, Kedisiplinan sekolah erat hubungannya dengan kerajinan siswa dalam sekolah juga dalam belajar. Termasuk 
kedisiplinan guru dalam mengajar karena dapat memberi contoh bagi peserta didik (Sulastri 2015).

Beberapa pendapat mengenai circuit learning menurut (Kirom and Sarofa 2017) mengemukakan bahwa menurut Miftahul Huda pengertian metode circuit learning merupakan metode pembelajaran yang memaksimalkan pemberdayaan pikiran dan perasaan dengan pula penambahan dan pengulangan. Menurut Aris Soimin pengertian metode circuit learning adalah memaksimalkan dan mengupayakan pemberdayaan pikiran dan perasaan dengan pola bertambah dan mengulang. Dan menurut Ahmad Rifai dalam bukunya ngalimun mengemukakan metode circuit learning adalah metode pembelajaran yang memaksimalkan pemberdayaan pikiran dan perasaan dengan pola tambah dan mengulang.

Menurut (Syahrial 2017) dalam bukunya Miftahul Huda langkahlangkah pembelajaran circuit learning sebagai berikut. Pertama, tahap persiapan, a). Melakukan apersepsi. b). Menjelaskan tujuan pembelajaran yang harus dicapai oleh siswa dalam pembelajaran hari ini. c). Menyampaikan cakupan materi dan penjelasan uraian kegiatan. Kedua, Tahap kegiatan inti. a). Melakukan tanya jawab tentang topik yang dibahas, b). Menempelkan gambar tentang topik yang dibahas c). Mengajukan pertanyaan tentang gambar yang ditempel, d). Menempelkan peta konsep yang telah dibuat, e). Menjelaskan peta konsep yang telah ditempel, f). Membagi siswa menjadi beberapa kelompok, g). Membagikan lembar kerja kepada setiap kelompok, h). Menjelaskan bahwa setiap kelompok harus mengisi lembar kerja siswa dan mengisi bagian dari peta konsep sesuai dengan bahasa mereka sendiri, i). Menjelaskan bahwa bagian dari peta konsep yang mereka kerajakan akan dipresentasikan, j). Melaksanakan presentasi bagian dari peta konsep yang telah dikerjakan, k). Memberikan penguatan berupa pujian atau hadiah atas hasil presentasi yang bagus serta memberikan semangat kepada mereka yang belum dapat pujian atau hadiah untuk berusaha lebih giat lagi, 1). Menjelaskan kembali hasil diskusi siswa tersebut agar wawasan siswa lebih luas. Ketiga, Tahap penutup, a). 
Memancing siswa untuk membuat rangkuman, b). Melakukan penilaian terhadap hasil kerja siswa.

Sedangkan kelebihan dalam menerapkan metode circuit learning antara lain kreativitas siswa dalam merangkai kata dengan bahasa sendiri lebih terasah dan konsentrasi yang terbangun membuat siswa fokus dalam belajar. Sementara kekurangan dalam menggunakan metode circuit learning, memerlukan waktu yang relatif lama dan tidak semua pokok bahasan dapat disampaikan dengan peta konsep (Kristiarti, Suripto, and Suryandari 2019).

Kegiatan atau aktivitas pembelajaran dirancang dengan tujuan untuk memfasilitasi siswa mencapai kompetensi atau tujuan pembelajaran. Pada konteks pengembangan kurikulum, kompetensi merupakan perpaduan dari pengetahuan, ketrampilan, nilai dan sikap, oleh karena itu tujuan yang ingin dicapai dalam kompetensi ini bukan hanya sekedar pemahaman akan materi pembelajaran, akan tetapi bagaimana pemahaman dan penguasaan materi dapat mempengaruhi cara bertindak dan berprilaku dalam kehidupan sehari-hari, yang secara khusus sekolah diselenggarakan dengan tujuan untuk mencerdaskan kehidupan bangsa, dan mengembangkan manusia seutuhnya (Suyono and Haryanto 2011). Model circuit laerning ini bertujuan untuk membuat siswa lebih mudah menangkap materi pokok yang disampaikan guru. Dengan menerapkan metode pembelajaran model circuit learning diharapakan dapat meningkatkan kreatifitas siswa dalam merangkai bahasa sendiri dan melatih konsentrasi siswa untuk fokus pada peta konsep yang disajikan guru (Hakim and D Mintohari 2015). Pada model circuit learning guru menyajikan materi berupa peta konsep, jadi siswa tidak harus menghafal semua materi, melainkan pokok-pokok materinya saja. Setelah guru menemukan model pembelajaran yang tepat dalam proses pembelajaran, guru juga bisa mendukung penggunaan model pembelajaran, supaya pengetahuan yang diterima siswa tidak salah tafsir. Kondisi kelas pada saat penggunaan metode circuit learning suasana kelas menjadi aktif dan fokus dalam mengerjakan tugas. Sebab gurunya tepat dalam penempatan dan pemilihan materi yang disampaikan. Ketika sudah 
terjadi hal yang demikian maka kemungkinan tingkat pemahaman siswa akan lebih tinggi. Dan akan mempengaruhi hasil belajar siswa itu sendiri, karena dia sudah nyaman dalam proses pembelajaran dan mudah untuk memahami suatu materi.

Proses pembelajaran pada hakekatnya merupakan proses interaksi antara guru dengan siswa yang didalamnya berisi aktivitas peserta didik melalui berbagai interaksi dan pengalaman belajar yang dialami oleh keduanya. Keaktifan belajar siswa merupakan salah satu unsur dasar yang penting bagi keberhasilan proses pembelajaran. Dalam Kamus Besar Bahasa Indonesia aktif berarti giat dalam bekerja atau berusaha. Kegiatan bekerja dan berusaha dilakukan oleh siswa dalam proses pembelajaran sesuai dengan materi pelajaran yang disampaikan oleh guru. Keaktifan adalah kegiatan yang bersifat fisik maupun mental, yaitu berbuat dan berfikir sebagai suatu rangkaian yang tidak dapat dipisahkan (Sardiman 2001). Macam aktifitas siswa dalam proses pembelajaran terbagi menjadi dua bagian, bagian pertama adalah aktifitas fisik dan yang kedua adalah aktifitas psikis. Aktifitas fisik adalah gerakan yang dilakukan siswa melalui gerakan anggota badan, gerakan membuat sesuatu, bermain maupun bekerja yang dilakukan oleh siswa di dalam kelas. Siswa sedang melakukan aktifitas psikis jika daya jiwanya bekerja sebanyak- banyaknya atau banyak berfungsi dalam rangka pembelajaran. Pentingnya keaktifan siswa dalam, pembelajaran dikatakan berhasil dan berkualitas apabila seluruhnya atau setidaktidaknya sebagian besar peserta didik terlibat secara aktif, baik fisik, mental maupun sosial dalam proses pembelajaran (Mulyasa 2002). Proses pendidikan di sekolah, tugas utama guru adalah mengajar sedangkan tugas utama setiap siswa adalah belajar. Belajar merupakan suatu proses, suatu kegiatan, dan bukan suatu hasil atau tujuan (Hamalik 2002). Belajar mengacu pada kegiatan siswa dan mengajar mengacu pada kegiatan guru. Mengajar pada dasarnya merupakan suatu usaha untuk menciptakan kondisi atau sistem lingkungan yang mendukung dan memungkinkan untuk berlangsungnya proses pembelajaran. Dapat disimpulkan bahwa keaktifan siswa dalam belajar merupakan segala kegiatan yang bersifat fisik maupun 
non fisik siswa dalam proses kegiatan belajar mengajar yang optimal sehingga dapat menciptakan suasana kelas menjadi kondusif (Sardiman 2001). Salah satu penilaian proses pembelajaran adalah melihat sejauh mana keaktifan siswa dalam mengikuti proses belajar mengajar. Keaktifan siswa dapat dilihat dalam hal: (1) turut serta dalam melaksanakan tugas belajarnya; (2) terlibat dalam pemecahan masalah; (3) Bertanya kepada siswa lain atau guru apabila tidak memahami persoalan yang dihadapinya; (4) Berusaha mencari berbagai informasi yang diperlukan untuk pemecahan masalah;(5) Melaksanakan diskusi kelompok sesuai dengan petunjuk guru;(6) Menilai kemampuan dirinya dan hasil- hasil yang diperolehnya; (7) Melatih diri dalam memecahkan soal atau masalah yang sejenis; (8) Kesempatan menggunakan atau menerapkan apa yang diperoleh dalam menyelesaikan tugas atau persoalan yang dihadapinya (Sujana 2002).

Berdasarkan uraian di atas dapat disimpulkan keaktifan siswa dapat dilihat dari berbagai hal seperti memperhatikan (visual activities), mendengarkan, berdiskusi, kesiapan siswa,bertanya, keberanian siswa, mendengarkan,memecahkan soal (mental activities). Faktor-faktor yang Mempengaruhi Keaktifan Keaktifan peserta didik dalam proses pembelajaran dapat merangsang dan mengembangkan bakat yang dimilikinya, peserta didik juga dapat berlatih untuk berfikir kritis, dan dapat memecahkan permasalahanpermasalahan dalam proses pembelajaran. Dalam upaya peningkatan keaktifan siswa guru dapat berperan dengan merekayasa sistem pembelajaran secara sistematis, sehingga merangsang keaktifan peserta didik dalam proses pembelajaran. Kegiatan-kegiatan guru yang dapat mempengaruhi keaktifan siswa adalah: 1) Memberikan motivasi atau menarik perhatian peserta didik, sehingga mereka berperan aktif dalam kegiatan pembelajaran; 2) Menjelaskan tujuan instruksional (kemampuan dasar kepada peserta didik); 3) Mengingatkan kompetensi belajar kepada peserta didik; 4) Memberikan stimulus (masalah, topik, dan konsep yang akan dipelajari); 5) Memberikan petunjuk kepada peserta didik cara mempelajari; 6) Memunculkan aktifitas, partisipasi peserta didik dalam kegiatan pembelajaran, 7) Memberikan umpan balik (feedback); 8) 
Melakukan tagihan-tagihan kepada peserta didik berupa tes sehingga kemampuan peserta didik selalu terpantau dan terukur; 9) Menyimpulkan setiap materi yang disampaikan diakhir pembelajaran. Keaktifan dapat ditingkatkan dan diperbaiki dalam keterlibatan siswa pada saat belajar (Usman 1993).

Berdasarkan penelitian dan hasil analisis observasi dan wawancara dengan beberapa siswa serta dewan guru di MA Sultan Agung Blora menunjukan bahwa dengan menerapkan metode circuit learning pada pembelajaran al Qur'an hadis, siswa mengalami perubahan, yaitu lebih memperhatikan saat proses pembelajaran dan mereka lebih cepat paham. Siswa terlihat senang, karena disini mereka bisa bekerja sama dengan kelompok kita, kita juga bisa bertukar pendapat tentang suatu masalah. Siswa bisa banyak-banyak bertanya pada guru tanpa harus malu. Siswa juga merasakan dengan memakai metode circuit learning saya lebih cepat faham karena saya bisa menjelaskan dengan bahasa mereka sendiri. Efektifnya metode ini juga bisa melatih jiwa keberanian siswa saat presentasi di depan kelas,mempresentasikan hasil diskusi kelompok yang diberikan oleh guru. Hal itu terjadi karena dalam metode circuit learning siswa dituntuk untuk aktif, berfikir kreatif,bekerja sama dengan kelompoknya dan yang pasti sering bertanya dengan guru. Siswa cukup senang dan antusias dalam proses pembelajaran ini. Saat proses pembelajarannya berlangsung rata-rata siswa menjawab dengan benar pertanyan-pertanyaan yang diberikan oleh guru kepadanya. Berikut hasil wawancara kepada peserta didik:

\section{KESIMPULAN}

Penggunaan metode circuit learning dapat membantu meningkatkan pemahaman dan hasil belajar siswa pada mata pelajaran Qur'an hadis, karena dalam metode ini siswa dituntut untuk aktif, kreatif, dan bekerja sama dengan kelompoknya. Siswa akan lebih tertarik jika selama proses pembelajaran terjadi interaksi yang baik, baik antara guru dengan siswa maupun siswa satu dengan siswa lainnya. Dengan demikian anak akan lebih 
senang untuk belajar dan cepat dalam memahami materi pelajaran dan yang akan berpengaruh pada hasil belajar siswa itu sendiri.

Saran dari penulis terkait pembelajaran Qur'an Hadist, setiap guru jangan berhenti untuk selalu berinovasi dan mencoba metode-metode baru dalam pembelajaran guna meningkatkan hasil belajar peserta didik. Perkembangan tekhnologi dan informasi tentu akan menuntut guru juga mengikutinya dikarenakan karakter dan pola fikir peserta didik juga tidak terlepas dari pengaruh perkembangan lingkungan yang ada di sekitarnya berada.

\section{REFERENSI}

Afandi, Muhamad. 2013. Model Dan Metode Pembelajaran Di Sekolah. Semarang: Unissula Press.

Anggito, Albi and Johan Setiawan. 2018. Metodologi Penelitian Kualitatif. Sukabumi.

Dalimunthe, Sehat Sultoni. 2016. Filsafat Pendidikan Akhlak - Penelusuran Google. Yogyakarta: CV Budi Utama.

Dewi, Dewa Ayu Puspa, I. Kmg Ngurah Wiyasa, and Ni Nym Ganing. 2014. "Pengaruh Model Pembelajaran Circuit Learning Berbantuan Media Audiovisual Terhadap Hasil Belajar Ips Siswa Sd Negeri 1 Pejeng Tahun Pelajaran 2013/2014." Jurnal Mimbar PGSD Universitas Pendidikan Ganesha Jurusan PGSD 2(1).

Hakim, AR and D Mintohari. 2015. "Pengaruh Model Circuit Learning Terhadap Hasil Belajar Siswa Tema Ekosistem Di Sekolah Dasar." $J P G S D$.

Hamalik, Oemar. 1995. Kurikulum Dan Pembelajaran. Bumi Aksara.

Hamalik, Oemar. 2002. Psikologi Belajar Mengajar. Bnadung: Sinar Baru Algessindo.

Kirom, Askhabul and Sarofa. 2017. "Penggunaan Metode Circuit Learning 
Dalam Pembelajaran Fikih.” Al Ghazwah 1.

Kristiarti, Anastasia, Suripto, and Kartika Chrysti Suryandari. 2019. "Pengaruh Model Pembelajaran Circuit Learning Berbantuan Media Flip Chart Terhadap Hasil Belajar IPA.” Kalam Cendikia 2(1).

Liatusyiam, Khila. 2016. "Implementasi Model Pembelajaran Circuit

Learning Untuk Meningkatan Hasil Belajar Siswa Pada Mata Pelajaran

IPS Kelas VII Di Mts Al Washliyah Talun Kabupaten Cirebon.”

Miftahul, Huda. 2013. Model-Model Pengajaran Dan Pembelajaran. Yogyakarta: Pustaka Pelajar.

Muhaimin. 2009. Rekonstruksi Pendidikan Islam: Dari Paradigma Pengembangan, Manajemen Kelembagaan, Kurikulum Hingga Strategi Pembelajaran. Depok: Raja Grafindo Persada.

Mulyasa. 2002. Manajemen Berbasis Sekolah: Konsep, Strategi Dan Implementasi. Bandung: Rosda Karya.

Rusman. 2017. Belajar \& Pembelajaran: Berorientasi Standar Proses Pendidikan. Jakarta: Kencana.

Sardiman. 2001. Interaksi Dan Motivasi Belajar Mengajar. Jakarta: Raja Grafindo Persada.

Shoimin, Aris. 2014. Model Pembelajaran Inovatif Dalam Kurikulum 2013. Yogyakarta: Ar-Ruzz.

Sujana, Nana. 2002. Dasar-Dasar Proses Belajar Mengajar. Bandung: Sinar Baru Algessindo.

Sulastri. 2015. "Meningkatkan Hasil Belajar Siswa Melalui Strategi Pembelajaran Berbasis Masalah Pada Mata Pelajaran IPS Di Kelas V SDN 2 Limbo Makmur Kecamatan Bumi Raya." Jurnal Kreatif Tadulako.

Suyono and Haryanto. 2011. Belajar Dan Pembelajaran. Bandung: Remaja Rosdakarya.

Syahrial. 2017. "Penerapan Strategi Pembelajaran Circuit Learning: Suatu

Upaya Dalam Meningkatkan Hasil Belajar Siswa.” Jurnal Ilmiah Dikdaya 9(2):285-92.

Timotius, Kris H. 2017. Pengantar Metodologi Penelitian: Pendekatan 
Manajemen Pengetahuan Untuk Perkembangan Pengetahuan. Yogyakarta.

Usman, Uzer. 1993. Upaya Optimalisasi Kegiatan Belajar Mengajar. Bandung: Remaja Rosda Karya. 